A N N A L E S

UNIVERSITATIS MARIAE CURIE-SKŁODOWSKA

LUBLIN - POLONIA

VOL. XXXIV

SECTIO FF

$1-2016$

\title{
JAN CZERNIAKIEWICZ
}

Uniwersytet Marii Curie-Skłodowskiej

\section{Морфологические функции праславянских альтернаций}

Morfologiczne funkcje alternacji prasłowiańskich

В славянском и русском языкознании широко изучены и описаны чередования (анг. alternation) вокальных и консонантных фонем как в корневых (анг. root), так и деревационных (англ. derivation) морфемах, а также во флексии (англ. Inflexion). Хорошо освещается этот вопрос и в иных индоевропейских языках преимущественно как констатация факта без указания на их функцию (Ежи Курилович - 1956: 402-423, 1957: 71-113, Вера Павловна Беседина-Невзорова - 1962: 69-87, Тадеуш Милевски - 1969: 309-326, Варвара Фёдоровна Кривчик - 1970: 57-59, Академическая Грамматика-70 - 1970 : 462-485, Георгий Александрович Хабургаев - 1974: 117-126, Радослав Бошкович - 1984: 37-38 , Зенон Клеменсевич - 1981: 177-180, Лешек Беднарчук - 1986: 25-26, Казимеж Полянски 2003: 38-39 и др - Вайлант 1966). Однако они представляют большую ценность, так как способствуют дальнейшему исследованию этой проблемы.

Чередования как вокальных, так и консонантных фонем в праславянском языке следует рассматривать по периодам развития самого языка. Известно, что праславянский язык существовал около трёх тысяч лет. На протяжении такого длительного времени в языке не могло не наступить никаких изменений в области фонологии, морфологии и лексики, а также в синтаксическом строе языка.

В нашей статье границы периодического развития языка будут условно определяться возникавшими значительными изменениями в его фонологической системе. На письме они будут обозначаться двумя косыми чёрточками //. 
Результаты сплошного лексико-морфологического исследования генетически родственных слов старославянского и современных языков, а также иных языков индоевропейской семьи́, делают возможной попытку реконструировать лексико-морфологическую структуру как периодическое ретроспективное развитие праславянского языка, так и последнего периода развития (периода распадения) общеиндоевропейского языка (о.и.е.), а также определить функцию чередований в однокоренном гнезде слов как в корневых, так и в аффиксальных морфемах.

Альтернацией (чередованием), как кажется, можно считать такую мену фонем, которая в определённом периоде развития языка использовалась вобразованиидругихчастейречиилиихформ. Фонемыиморфемычередования будем называть а л ь т е рн а н т а м и. Известо, что в первом периоде развития праславянский язык располагал унаследованной фонологической системой из (о.и.е.) как консонантными, противопоставлявшимися придыхательным элементом $[\mathrm{h}]$, так и вокальными по длительности и краткости. При отсутствии словесного ударения, такие фонемы могли выполнять свою функцию, так как произношение речи было посложное. Затем такая фонологическая система начала упрощаться под влиянием развития в языке музыкального ударения, выравнивавшего тон в слове и слоге, (Чернякевич 2003: 107), т.е. консонантные потеряли свой придыхательный элемент [h], а вокальные - длительность и краткость. Развитие музыкального словесного ударения также способствовало перераспределению границ слогов. А это привело к стечению двух вокальных или двух одинаковых по качеству консонантных , что препятствовало плавности произношения. Язык вынужден был устранять такое явление, т.е. такие вокальные выпадали, а предидущий из консонантных диссимилировался или выпадал.

Альтернация фонем или морфем в определённом периоде существования языка могла являться формо- словообразовательной или выполняла чисто фонетическую функцию, например: *[ghŏrētřs // > gŏrētǐs $(\mathrm{gh}>\mathrm{g})$ // gorětıs ( $\breve{0}>$ o, $\overline{\mathrm{e}}>\mathrm{e}, \breve{1}>$ ь) // > gorětь] > ст-сл. горє'тти, рус. гореть, белорус. гарэць, польск. gorzeć, серб. горјети, чеш. horeti. Ср.: лит. garèti - “жечь”, др.-инд. gorim - “грею”: и * [ghērŭs // > gērŭs // > gěrъs > ž 'е̌rъ > Ž - “высокостволый “, жаравъый - “горящий”, рус. жар, белорус. жар, польск. żar. Cp. арм. ger - "тёплый”, germ - “горячий”, др-инд. haras - “жар”, курд. gärm - "горячий” В этом однокоренном гнезде альтернанты *[б : o; е̄ : е̌ : 'a : a; gh : g : ž] выполняло чисто фонетическую функцию - они выравнивали тон в слове, а альтернанты в корневой морфеме *[б : е : е̌ : a ] - словообразовательную: образование отглагольного существительного.

Мена звуков в составе морфемы, происходившая в процессе длительного развития языка, является чисто фонетическим фактором, вызванным определённой языковой закономерностью, возникшей в праславянском языке 
в процессе его существования - развитием того же музыкального ударения. Такая альтернация не отыгрывала никакой роли в образовании лексем или их форм, а лишь приводила к качественным изменениям тех альтернантов. Они являлись аллофонами исходных фонем, например: *[mĭglās // > mьglas // > mgla] > ст.-сл. мьгма, рус . мгла - "пелена тумана, пыли “, польск. mgła. Cp.: лит. migla - “туман”, латыш. - “тж.”, нидерл. miggelen - “моросить“, др-инд. mih - “дождь“, арм. mēg - “туман”, санскр. meghás - “облако”. Здесь мена звуков * [ $\mathbf{\mathbf { i }}: \mathbf{b}: \boldsymbol{\varnothing}]$ не изменяла семантики данного слова. В выше рассмотренном однокоренном гнезде чередование консонантных звуков $[\mathbf{g h}: \mathbf{g}: \mathbf{z}]$ также являлось фонетическим фактором. Результаты мены звуков этих двух примеров связаны с развитием того же музыкального ударения.

Альтернация в знаменательных частях речи

В лингвистике существуют термины парные и непарные глаголы. Зиждутся они на способности противопоставления действия или состояния их видовых пар. Основываются они на мене звуков фонологического состава в корневых морфемах (англ. root morphem) или на чередовании аффиксальных морфем (англ. affixal morfem).

\section{Двухвидовые глаголы ( англ. bi-aspectual) *[dōdh-] - "благотворить"}

О.и.е. корневая морфема *[dōdh-] с суффиксом инфинитива *[-ť̄-] и указателем границы слова *[-s] послужила развитию глагольной формы одно-

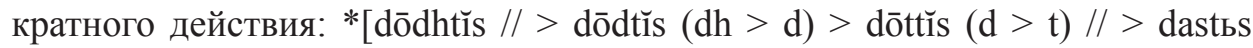
$(\mathrm{t}>\mathrm{s}, \overline{\mathrm{o}}>\mathrm{a}, \breve{\mathrm{l}}>\mathrm{b})>/ />$ datьs $(\mathrm{s}>\varnothing)>$ datь] $>$ ст-сл. Аати -“"дать”, рус. дать, белорус. даць, (диал.) дасьці, польск. dać. Ср. : зенд. dadhati, санскр. dadati, др.-инд. dadāti - “даёт”, греч. [didōmi] - “даю”. В этой глагольной форме альтернанты вокальных *[ō : a] и консонантных *[dh : d] послужили выравниванию тона в слове.

Личные глагольные формы нетематических глаголов развивались от корневой морфемы *[dōdh-] посредством соответствующих окончаний с указателем завершения слова *[-s]: (1-е лицо ед. ч.) *[dōdhmĭs $/ />$ dōdmĭs $(\mathrm{dh}>\mathrm{d})>\operatorname{dōmĭs~}(\mathrm{dm}>\mathrm{m})>\operatorname{dōmĭs}(\mathrm{d}>\varnothing)>\operatorname{dambs}(\overline{\mathrm{o}}>\mathrm{a}, \breve{\mathrm{l}}>\mathrm{b})>$ damь $]>$ cт. сл. Аамь, рус. дам, белорус. дам, польск dam; (2-е лицо ед. ч.) *[dōdhš̆s // >

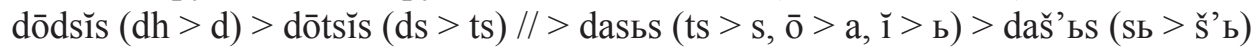
$>$ daš’ь] > ст.-сл. Ааси, рус. Аашь, белорус. дасі, польск. dasz; (3-ье лицо ед. ч.) *[dōdhtŭs $/ />$ dōdtŭs $(\mathrm{dh}>\mathrm{d})>$ dōttŭs $(\mathrm{dt}>\mathrm{tt})>$ dōstŭs $(\mathrm{tt}>\mathrm{st}) / />$ dastъs

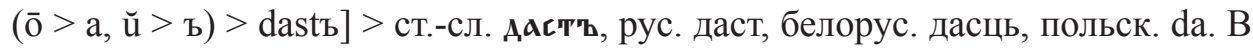
данном однокорневом гнезде в личных формах глагола в корневых морфе- 
мах альтернация наблюдалась как вокальных *[р : a], так и консонантных *[dh : d : ø], способствовавшая выравниванию тона в слове. Также альтернация выступала и в окончаниях личных глагольных форм: фонетическая

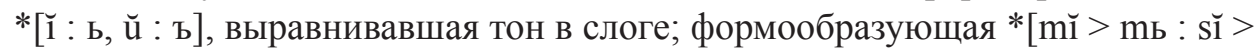
sь $>$ š's : tŭ $>$ tъ], сохраняя корневую фонему *[dh] с последующими её аллофонами *[d : $t: \varnothing]$.

Та же о.и.е. корневая морфема *[dōudh-] явилась источником для образования глагольной формы кратного действия посредством альтернации

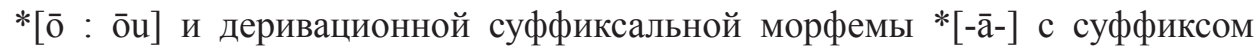
инфинитива *[-ť̄-]: *[dōudhātǔs // > *[dōudātřs $(\mathrm{dh}>\mathrm{d}) *$ [dōuātřs $(\mathrm{d}>\varnothing) / />$ davatbs ( $\bar{o} u>a v, \bar{a}>$ a, $\breve{1}>$ b) // > davatь $>>$ ст-сл. далти - “давать”, рус. давать, белорус. даваць, польск. dawać, чеш. davati, серб. давати. Ср.: лит. dúoti “да-

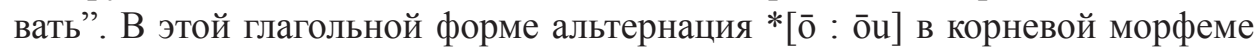
выполняла формообразовательную функцию, но чередование вокального * $[\overline{0}: \mathrm{a}, \overline{\mathrm{a}}: \mathrm{a}, \breve{1}: \mathrm{b}]$ и консонантных *[dh : d : $]$ послужили выравниванию тона в слове, т.е. выполняли чисто фонетическую функцию.

В данной паре глаголов в о.и.е. корневой морфеме альтернанты [ō : ōu] выполняли функцию образования противоположных видов. Кроме того для развития кратной формы глагола была использована деривационная суффиксальная морфема *[-ā-].

От о.и.е. корневой мофемы *[dōdh-] развились существительные с незначительной семантической разницей посредством суффиксальных морфем: a) при помощи деривационной морфемы *[-r-] и окончанием *[-ā-]: *[dōdhrŭs $/ />$ dōdrŭs $(\mathrm{dh}>\mathrm{d}) / />$ darъs $(\overline{\mathrm{o}}>\mathrm{a}, \mathrm{d}>\varnothing, \breve{\mathrm{u}}>\mathrm{b}) / />$ darъ] $>$ ст.сл. Ааръв, рус. дар, белорус. падарунак, польск. podarunek. Ср.:греч. [dōron] - “дар, подарок”, лат. dare - “давать”; б) посредством деривационных морфем *[-ai-, -ĭn-, -иi-] с окончанием *[-ё-]: *[dōdhaiǔnĭiĕs $/ />$ dōdaiīnĭiěs (dh $>$ d) $/ />$ daěьnьies $(\mathrm{d}>\varnothing$, ai $>$ ě, $\breve{n}>$ bn, $\breve{i}>$ bi, $\breve{e}>$ e ) $>$ daěønøies ( ьn > øn, ьі > øi) > daе̌ønøie] > ст.-сл. Аа‘ние - “дар", белорус. дар, рус. дар, даяние (уст.) - "пожертвование"; в) с помощью деривационных морфем

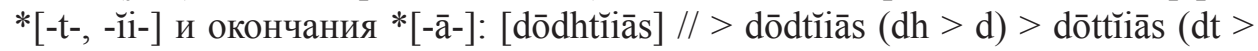
tt) $/ />$ datbias (tt $>$ t, $\bar{o}>$ a, $\breve{i}>>$ bi, $\bar{a}>$ a) $>$ datøjas $($ bi $>ø j)>$ dač'as (tøj $>$ č') $>$ dač'a] > ст.-сл. дача - “угодья и земли“", др.-рус. дачька - “дар”, рус. дача - “то, что даётся", белорус. дача. Ср.: греч. [dōtis, dosis] - “дар, подарок”. Морфологические альтернанты: в корнемой морфеме *[d : r], в суффиксальных морфемах *[ø: $\bar{a}, \breve{n}, \breve{i i}, \mathrm{t}, \mathrm{ii}]$ в рассматриваемых существительных выполняли словообразовательную функцию, так как они выступали в одной и той же части речи, но изменяли семантику каждой из лексем, а выпадение в корневой морфеме консонантного *[-t- $<-\mathrm{d}-<-\mathrm{dh}-]$ послужило созданию плавности произношения, т.е. выравниванию тона в слове. 
Одно из рассматриваемых существительных послужило развитию близкой по значению глагольным формам данного однокоренного гнезда.

Основа *[dōdhr-] существительного *[dōdhrŭs // > darъs // > darъ] послужила развитию глагольных форм посредством деривационных суффиксальных морфем: a) *[-о̆u-, -ā-] с суффиксом инфинитива *[-ť̄-] развилась глагольная форма однократного дейстия: *[dōdhrŏuātǐs // > dōdrŏuātǐs (dh > d) $>$ darovatıs $(\mathrm{d}>\varnothing, \overline{\mathrm{o}}>\mathrm{a}, \mathrm{ou}>\mathrm{ov}, \overline{\mathrm{a}}>\mathrm{a}, \mathrm{i}>\mathrm{b}) / />$ darovatъ $]>$ рус. даровать (свободу), белорус. дараваць, польск. darować - "даровать". В этой глагольной форме альтернанты *[dh : d : ø, ō : a, ŏu : ov, $\bar{a}: \mathrm{a}, \breve{1}:$ ь ] выполняли чисто фонетическую функию, а альтернанты *[ø : ŏu, $\bar{a}]-$ словообразователную; б) *[-еi-] с суффиксом инфинитива образовалась глагольная форма кратного действия: *[dōdhreitǐs // dōdreitǐs $(\mathrm{dh}>\mathrm{d})>$ dōreitı̌s $(\mathrm{d}>\varnothing) / />$ daritьs $(\overline{\mathrm{o}}>\mathrm{a}$, ei $>$ i, $\breve{1}>$ ь) $>$ daritь] $>$ рус. дарить, белорус. дарыць, польск. darzyć. B pacсматриваемой глагольной форме альтернанты *[ $\mathrm{dh}: \mathrm{d}$, ei : i, $\mathrm{l}:$ ь] выполняли чисто фонетическую функцию], но альтернанты суффиксальных морфем *[ø : еi] - словообразовательную, так как они послужили развитию противоположных глагольных форм.

Личные формы глагола развились от основы инфинитива *[dōrei-] посредством суффиксальных морфем *[-о̆-, чаний: (1-е лицо ед. ч) *[dōdhreiǒı̆ions $/ />$ dōdreiŏĭions $(\mathrm{dh}>\mathrm{d})>$ dōreiŏĭions $(\mathrm{d}>\varnothing) / />$ dariobiQs $(\overline{\mathrm{o}}>\mathrm{a}$, ei $>\mathrm{i}, \breve{\mathrm{o}}>$ o, $\mathrm{i}$ i $>$ bi, on $>$ Q) $/ />\operatorname{dariQs}($ io $>$ iø, bi $>\varnothing)$ $>$ dar'iQ] > ст.-сл. Аарюқ, рус. дарю, белорус. дару, польск. (przest.) darzę; (2-е

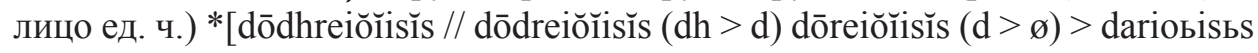

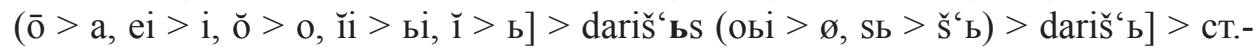
сл. Аариши, рус. даришь, белорус. до́рыш, польск. darzysz; (3-ье лицо ед. ч.)

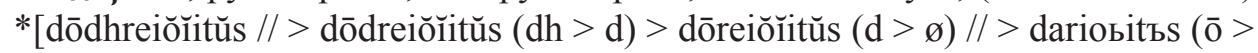

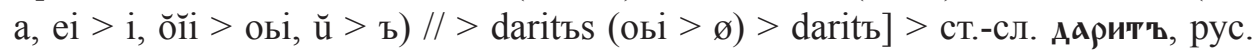
дарит, белорус. до́рыць, польск. darzy. Альтернанты *[ dh : d, d : ø, ō : a, ei :

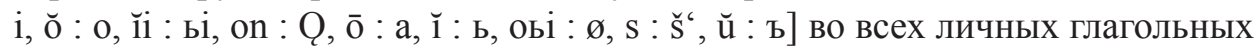
формах выполняли чисто фонетическую функцию, а альтернанты личных глагольных окончаний *[on $\left.>\mathrm{Q}, \mathrm{s}>\breve{\mathrm{s}}^{\varsigma}: \mathrm{t}\right]$ - формообразовательную функцию.

$$
\text { *[ghoi-] - “сиять пустотой” }
$$

О.и.е. корневая морфема *[ghoi-] послужила развитию глагольной формы кратного действия без деривационной суффиксальной морфемы с суффиксом инфинитива *[-ť̆-]: *[ghoiť̌s // > goiť̌s $(\mathrm{g}<\mathrm{gh}) / />$ gětbs $(\check{\mathrm{e}}<\mathrm{oi}, / /$ $>$ zětьs $(\mathrm{z}<\mathrm{g})>$ zětь] > ст.-сл. Зети - "зиять, раскрываться", польск. ziać. В данной глагольной форме альтернанты * $[\mathrm{gh}: \mathrm{g}$, oi : е̌, g : z, ц : ь ] выполняли чисто фонетическую функцию. 
Та же о.и.е. корневая морфема * [ghoi-] явилась производящей в образовании глагольной формы однократного действия посредством альтернанта в корневой морфеме *[oi : еi] и с использованием деривационной суффиксальной морфемы *[-non-], а также суффикса инфинитива *[-ť̆-]: *[gheinontǐs $/ />$ geinontĭs $(\mathrm{g}<\mathrm{gh}) / />$ zinQtbs $(\mathrm{z}<\mathrm{g}, \mathrm{i}<$ ei, $\mathrm{Q}<$ on, ь $<\breve{1})>$ zinQtb $]>$ ст.сл. зимяти - “зевнуть” др.-рус. зиняти, рус. зевнуть, белорус. пазяхнуць, польск. ziewnąć. В этой глагольной форме альтернанты *[gh : g, g : z, ei : i, on : Q, $\breve{1}:$ ь] выполняли чисто фонетическую функцию, а альтернанты в корневых морфемах *[оі : еі] - формообразовательную.

Также выступала в праславянском языке и глагольная форма постоянного действия, которая развилась от о.и.е. корневой морфемы *[ghoi-] глагола однократного действия посредством мены в корневой морфеме *[oi : еi] и при помощи деривационных суффиксальных морфем *[-йі-, -ā-] с суффик-

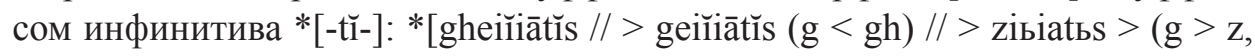
ei $>$ i, $\breve{i i}>$ bi, $\bar{a}>$ a,$\breve{i}>$ b) $>$ zibiatьs $>$ ziøjatьs $($ bi $>\varnothing j)>$ zijatьs $>$ zijatь $]>$ ст.-сл. зїлти - “раскрывать рот”, рус. зиять - „быть раскрытым”, белорус. зеўраць, польск. ziać.

Та же корневая морфема о.и.е. языка *[ghoi-] послужила развитию существительных посредством деривационных суффиксальных морфем: а) посредством деривационной суффиксальной морфемы *[-1и-] с окончанием *[ŭ]: *[ghoiйuŭs $/ />$ goiйuŭs $(\mathrm{g}<\mathrm{gh})>$ zoiйuŭs $(\mathrm{z}<\mathrm{g})>$ zěьuъs $>(\check{e}<$

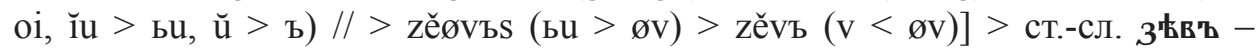
“щель, отверстие", рус. (уст.) зев - “вход из полости рта в глотку", польск. ziew. В данном существительном альтернанты *[gh : g, g : z, oi : е̌, ı̆u : ьu, $\breve{\mathrm{u}}:$ ь , ьu : øv] выполняли чисто фонетическую функцию, но суффиксальный альтернант *[ø: й $]$ - словообразовательную; б) при помощи деривационных суффиксальных морфем *[-an-, -йi-] с окончанием *[-ё-]: *[ghoiйuanĭiĕs

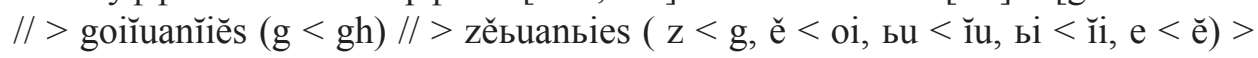

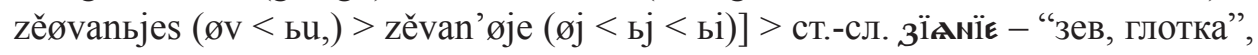
рус. зевание, белорус. пазяханне, польск. ziewanie. В этоом существительном альтернанты *[gh : g, g : z, oi : е̌, ц̆u, : ьu : øv, е̌ : e, ц̌i : ьі : ьj : øj] выполняли чисто фонетическую функцию, а альтернанты суффиксальных морфем *[ø : an, цii] - словообразовательную.

От основы существительного *[zěv- < zěvъ $<$ ghoiйuŭs] образовалась вторичная глагольная пара: а) кратного действия - посредством деривационной суффиксальной морфемы *[-ā-] и суффикса инфинитива *[-ť̃-]: *[ghoiruuātřs // $>$ goiñuātǐs $(\mathrm{g}<\mathrm{gh}) / />$ zěbuatbs $(\mathrm{z}<\mathrm{g}$, ě $<$ oi, bu $<\breve{1 u}, \mathrm{a}<\overline{\mathrm{a}}, \mathrm{b}<\breve{1})>$ zěøvatıs (øv $<$ bu) > zěvatь] > ст.-сл. 3'中ти- “зевать”, рус. зевать, белорус. пазяхаць, польск. ziewać, чеш. zivati - "зевать". В данной глагольной форме альтернанты *[gh : g, g : z, oi : е̌, йu : ьu : øv, $\breve{1}:$ ь] выполняли чисто фонетическую функцию, 
а альтернанты суффиксальных морфем *[ø : $\bar{a}]$ - словообразовательную; б) однократного действия - при помощи деривационной суффиксальной морфемы *[-non-] с суффиксом инфинитива *[-ť̃-]: *[ghoiňunontǐs // > goiĭunontĩs

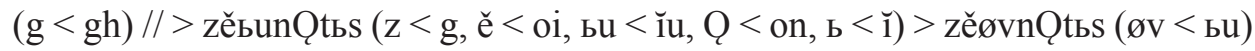
$>$ zěьvnQtь] > ст.-сл. зикяти - "разинуть", рус. зевнуть, белорус. пазяхнуць, польск. ziewnąć. В этой глагольной форме альтернанты * $[\mathrm{gh}: \mathrm{g}, \mathrm{g}: \mathrm{z}$, oi : е̌, $\breve{1 u}:$ bu : øv, on : Q, $\breve{1}:$ ь] выполняли чисто фонетическую функцию, но альтернанты суффиксальных морфем *[ø : non] - словообразовательную.

$$
\text { *[krī-] - “вопль” }
$$

О.и.е. корневая морфема *[krī-] послужила развитию глагольной формы кратного действия посредством деривационных суффиксальных морфем *[-ks-, -ё-] с суффиксом инфинитива *[-tī-]: *[krīksētǐs $/ />$ krīkētǐs $(\mathrm{ks}>\mathrm{k})>\operatorname{krikětbs}(\overline{\mathrm{i}}>\mathrm{i}, \overline{\mathrm{e}}>\check{\mathrm{e}}, \breve{1}>\mathrm{b}) / />\operatorname{kričětbs}(\mathrm{k}>\mathrm{c})>\operatorname{krič}{ }^{\prime} \mathrm{ětb}>$ krič‘ atb (ё > 'a)] > ст.-сл. кричати, рус. кричать, белорус. крычаць, польск. krzyczeć. Cp.: лит. kriksèti - “покрикивать”, др.-герм. hrika - “скрежетать”, греч. [krike] - “визжи”. В этой глагольной форме альтернанты *[1 : i, ks : k : č, е̄ : е̌ : a, $\breve{1}:$ ь] выполняли чисто фонетическую функцию.

Та же о.и.е. корневая морфема *[krī-] явилась основанием для образования однократной формы глагола при помощи деривационных суффиксальных морфем *[-ks-, -non-] с суффиксом инфинитива *[-ť̄-]: *[krīksnontǐs // > krîknontǐs $(\mathrm{ks}>\mathrm{k})>\operatorname{kriknontbs}(\overline{\mathrm{i}}>\mathrm{i}, \breve{1}>\mathrm{b}) / />\operatorname{kriknQtbs}($ on $>Q)>\operatorname{kriknQtb}]>$ ст.-сл. крикнжти, рус. крикнуть, белорус. крыкнуць, польск. krzyknąć. В данной глагольной форме альтернанты *[ $\mathrm{ks}: \mathrm{k}, \overline{1}: \mathrm{i}$, on : Q, $, \mathrm{i}:$ ь $]$ выполняли чисто фонетическую функцию, выравнивая тон в слове, а мена суффиксальных морфем *[ks : ø, e : non] - формообразовательную функцию.

Существительное развилось от той же корневой морфемы *[krī-] посредством деривационной суффиксальной морфемы *[-ks-] и окончания *[-ŭ-]: *[krīksŭs $/ />\operatorname{krīkŭs~}(\mathrm{ks}>\mathrm{k}) / />\operatorname{krikъs}(\overline{\mathrm{i}}>\mathrm{i}, \breve{\mathrm{u}}>$ ь) $>$ krikъ] $>$ ст.сл. кричь, кричава - “крик, вопль”, рус. крик, белорус. крык, польск. krzyk. В этой лексеме мена фонем *[ks : k, $\overline{1}: \mathrm{i}, \breve{\mathrm{u}}:$ ь $]$ являлась чисто фонетической, выравнивавшей тон в слове, а альтернанты *[ø: ks] выполняли словообразовательную функцию.

Действительные причастия прошедшего времени (несклоняемые) развились от основ инфинитива с суффиксом *[-1-] с окончанием *[-ŭ-]: a) от основы *[krīksē-] глагольной формы *[krīksētřs]: *[krīksēlŭs // > krīkēlŭs (ks $>\mathrm{k}) / />$ krīkēlŭs $>$ kričělıs $\left(\mathrm{k}>\check{c}^{\prime}, \overline{1}>\mathrm{i}, \overline{\mathrm{e}}>\mathrm{e}, \breve{\mathrm{u}}>\mathrm{b}\right)>$ krič‘ělıs $>$ krič'alı (е̌ $>$ 'a)] $>$ ст.-сл. кричал’z, рус. кричал, белорус. крычаў, польск. krzyczał. Здесь причастие продолжительного действия развилось посредством деривационной суффиксальной морфемы *[-1-], а альтернанты фонем *[ks : k, $1: \mathrm{i}$, 


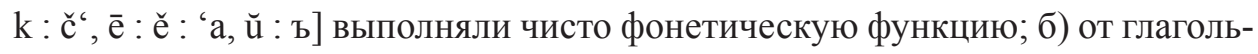
ной основы *[krīksnon-] глагола *[krīksnontǐs]: *[krīksnonlŭs // $>$ krīknonlŭs

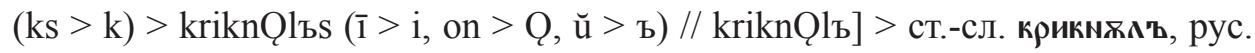
крикнул, белорус. крыкнуў, польск. krzyknął. Данное причастие, выполнявшее однократное действие, образовалось от глагольной основы однократного действия с помощью той же суффиксальной морфемы *[-1-] и окончания

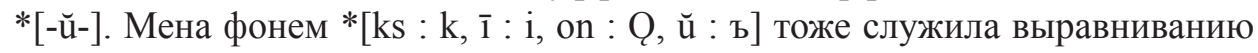
тона в слове, но суффиксальная морфема *[-1-] в этих двух причастных вариантах выполняла формообразовательную функцию.

Прилагательное развилось от основы существительного *[krīks-] с помощью деривационных суффиксальных морфем *[-1-, -іu-] и окончания *[-ŭ-]: *[krīkslīuŭs // krîklīuŭs $(\mathrm{ks}>\mathrm{k}) / />$ kriklivъs $(\overline{\mathrm{i}}>\mathrm{i}, \overline{\mathrm{i}} \mathrm{u}>\mathrm{iv}, \breve{\mathrm{u}}>$ ๖] $) / /$ $>$ kriklivъ] > ст,-сл. крикмивъ, рус. крикливый, белорус. крыклівы, польск. krzykliwy. В этом прилагательном чередование фонем *[ks : k, 1 : i, îu : iv, $\breve{\mathrm{u}}:$ ъ $]$ было чисто фонетическим, а альтернация морфем *[ø: $1, \mathrm{iu}<\overline{\mathrm{lu}}]$ послужила образованию части речи, т.е. это чередование выполняло словообразовательную функцию.

Непарные глаголы (англ. non-pair verb)

$$
\text { *bei-] - "удар" }
$$

Непарные глаголы - по сути дела они тоже парные. Противоположность действия или состояния непарных глаголов в праславянском языке достигалась посредством некоторых служебных слов, впоследствии ставшими префиксальными морфемами, например, от глагольной формы кратного действия, образовавшаяся бессуффиксальным путём с помощью инфинитивной

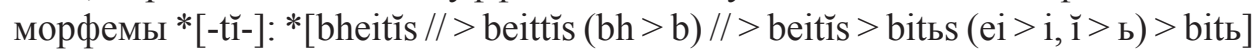
развились формы однократного действия: *[ ŏns $>$ nōs $>$ na] $>$ pyc. на, польск. na. Ср.: лат. an, гот. ana, греч. [ana]; [pěrs $>$ pērs $>$ prěs $>$ prě $]>$ pyc. пере, польск. prze. Ср.: др-прусск. prei - “на, к, у", лат. prae - "перед, от", греч. [parai] - "около"; *[ŏus > ous $>$ ou $>$ u] $>$ pyc. у. белорус. у, польск. и. Ср.: др.-прусск. au - “от”, латыш. оu - “тж.”, лат. au - “y”, др.-инд. ava - “тж.” и др.: * [ŏns bheitı̌s // > nōs beiť̃s $(\breve{o}>\overline{\mathrm{o}}, \mathrm{bh}>\mathrm{b}) / />$ nas beiť̃s $>$ nabitıs $(\overline{\mathrm{o}}>\mathrm{a}$, ei $>\mathrm{i}, \breve{1}>$ b) $>$ nabitь $]>$ pyc. набить, белорус. набіць, польск. nabić; *[pěrs bheiť̃s $/ />$ prēs beitǐs $(\check{e}>\bar{e}, b h>b) / />$ prěbitbs $(\overline{\mathrm{e}}>\mathrm{e}$, ei $>\mathrm{i}, \breve{\mathrm{i}}>\mathrm{b})>$ prěbitb $]>$ ст-сл. прњьити - “перебить”, рус. перебить, белорус. парабиць. Альтернанты в данных глагольных формах *[ō : a, ě : ē : ě, bh :b, ei : i, ı̆ : ь] выполняли чисто фонетическую функцию, а альтернанты деривационных префиксальных морфем *[ŏns : pěrs] - формообразовательную функцию.

Личные глагольные формы развились от глагольной корневой морфемы посредством мены дифтонгов в корневой морфеме *[еі : йi] и при помощи 
деривационных морфем *[-о̆-, -йi-]: (1-е лицо ед. ч.) *[bhřiǒĭions // > bŭiǒĭions (bh $>$ b) $>$ bьiobions $(\ddot{i i}>$ bi) $>$ bьjjons $(\mathrm{o}>\varnothing$, bi $>$ j) $>$ bьjons $(\mathrm{jj}>\mathrm{j}) / />$ bøjQs (on > Q) > bøjQ] > ст.-сл. кин, рус. бью, белорус. б'ю, польск. biję; (2-е лицо

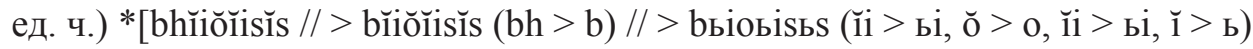

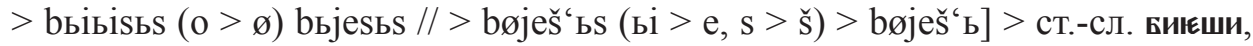
pyc. бьёшь, белорус. б'еш, польск. bijesz; (3-е лицо ед. ч.) *[bhĭiǒĭětŭs // >

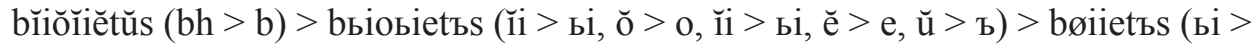
øj, оь $>\varnothing)>$ bøjјеtъs $>$ bøjetъ $(\mathrm{jj}>\mathrm{j})]>$ ст.-сл. Биєєтъ, рус. бьёт, белорус. б’е, польск. bije. Альтернанты в корневой морфеме *[еі : йi] и суффиксальная

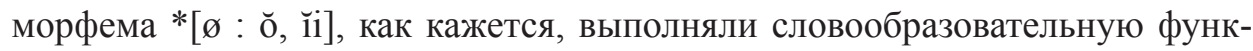
цию, а альтернанты в окончаниях *[on $\left.>\mathrm{Q}, \mathrm{s}>\breve{s}^{\prime}, \varnothing: \mathrm{t}\right]$ - формообразова-

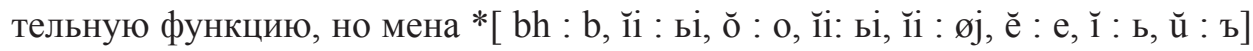
- выполняла чисто фонетическую функцию.

От данных глагольных форм развились страдательные причастия прошедшего времени посредством деривационной суффиксальной морфемы *[-t-] с окончанием *[-ŭ-]: a) от глагольной формы кратного действия: *[bheitŭs $/ />$ beitŭs $(\mathrm{bh}>$ b) $/ />$ bitъs $($ ei $>$ i) $/ />$ bitъ] $>$ ст.-сл. кит' польск. bity; б) *[ŏns beitŭs $>$ nōs beitŭs $(\breve{o}>\bar{o})>$ nabitъs $($ ei $>$ i) $>$ nabitъ $]>$ ст.-сл. накит'ъ, рус. набит, польск. nabity; *[pěrs bheitŭs $/ />$ prēs beitŭs (ě $>$ $\overline{\mathrm{e}}, \mathrm{bh}>\mathrm{b}) / />$ prěbitъs $*(\overline{\mathrm{e}}>$ ě, ei $>$ i) prěbitъ] $>$ ст.-сл. пр'ьиттъ, рус. перебит, белорус. парабіты, польск. przebity. Альтернация в данных глагольных формах выполняла две функции: а) чисто фонетическую, выравнивавшую тон в слоге и слове *[ е̌ : $\bar{e}, b h: b, \bar{e}:$ ě, ei : i]; б) - слово- формообразовательную *[ŏns : perrs, $\varnothing: t]$.

Развитие существительных от глагольной корневой морфемы *[bhei-] осуществлялось двумя способами: а) бессуффиксальным путём за счёт альтернанта *[-оi-] в корневой морфеме и окончания *[-ŭ-]: *[bhoiŭs // > boiŭs (bh $>$ b) $/ />$ boiъs $(\breve{\mathrm{u}}>$ b) $>$ bоіь] $>$ ст.-сл. кой - “битва", рус. бой, белоpус. бой, польск. bój; б) с помощью суффиксальных морфем, например: *[-t-, -ŭu-] и окончания *[-ā-]: *[bheitŭuās // > beitŭuās $(b h>$ b) $/ />$ bitbvas $($ ei $>$ i, ŭu $>$ bv, à $>$ a) $/ />$ bitøvas $(\varnothing v>v)>$ bitvas $>$ bitva] $>$ pyc. битва, белорус. бітва, польск. bitwa. В этой части речи альтернанты *[bh : b, ei : i, ŭu : bv, ā : a] выполняли чисто фонетическую функцию, а мена в корневых морфемах дифтонгов *[ei : оi] служила для образования другой части речи, т.е. выполняла словообразовательную функцию.

$$
\text { *[gnei-] - “разлагаться” }
$$

О.и.е. корневая морфема *[gnei-] с суффиксом инфинитива *[-ť̃-] явилась исходной для развития глагольной формы продолжительного состояния * [gneitřs // > gnitьs $($ ei $>\mathrm{i}, \breve{1}>$ ь) // > gnitbs > gnitь] > ст.-сл. гнити 
- “гнить”, рус. гнить, белорус. гнісці // гніць, польск. gnić. Ср.:др.-в.-нем. gnitan - "растирать”, латышск. gnīde - “потёртая кожа", греч. [gniei] - "распадаться на части”. В данной глагольной форме альтернанты *[еі : i, ı̆ : ь] выполняли чисто фонетическую функцию.

О.и.е. корневая морфема *[gnei-] послужила развитию глагольной формы однократного состояния посредством служебных слов, впоследствии ставшими префиксальными морфемами, с суффиксом инфи-

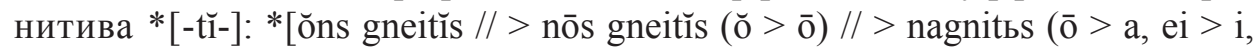
$\breve{1}>$ ь) > nagnitь] > ст.-сл. магмити, рус. нагнить, белорус. нагніці, польск. nagnić; *[pĕrs gneiť̃s // > prēs gneitřs $(\breve{\mathrm{e}}>\overline{\mathrm{e}}) / />$ prěgnitbs $(\overline{\mathrm{e}}>\mathrm{e}$, ei $>\mathrm{i}, \breve{1}>$ b) $>$ prěgnitь] > ст.-сл. пюњгмити, рус. перегнить, белорус. перагнісці // перагніць, польск. przegnić. В этой глагольной форме * $[\bar{o}>\mathrm{a}, \mathrm{ei}>\mathrm{i}, \breve{1}>$ b, $\breve{\mathrm{e}}>\overline{\mathrm{e}}]$ выполняли чисто фонетическую функцию, но чередования префиксальных морфем *[na $<$ ŏns, prě $<$ perrs] служили образованию слов иного значения.

Существительные развились от глагольной морфемы *[gnei-] двумя способами: а) бессуффиксальным путём посредством замены альтернанта *[ei] на *[oi] в корневой морфеме и окончания *[-ŭ-]: *[gnoiŭs $/ />\operatorname{gnojъs~}(\breve{\mathrm{u}}>$ ь) $/ />$ gnојъ] > ст.-сл. гмой - “болячка, навоз”, рус. гной, белорус. гной, польск. gnój; б) морфологическим способом, т.е. при помощи суффиксальной морфемы, например, *[-1-] с окончанием *[-1̌-]: *[gneilǐs // > gnilьs (ei $>\mathrm{i}, \breve{1}>$ ь) // > gnilь $]>$ pyc. гниль, белорус. гніль, польск. zgnilizna. В существительном *[gnojъ < gnoiŭs] мена в корневой морфеме *[ei : oi], видимо, связана с восходящей интонацией, а в существительном * [gnilь < gneilǐs] сохранялась нисходящая интонация глагольной формы; мена альтернанта в суффиксальной морфеме *[ø : 1] выполняла словообразовательную функцию. В то же время альтернанты *[еi : i, $\breve{1}:$ ь $]$ служили выравниванию тона в слове.

Корневая морфема *[gnoi-] существительного *[gnoiŭs] с деривантной морфемой *[-̄-] и суффиксом инфинитива *[-ť́-] явилась исходной при образовании глагольной формы принудительного действия: *[gnoiītřs // > gnoiitbs (oi > oj, î̀ > i) // > gnojitь] > ст.-сл. гмоити - “испрагаться”, рус. гноить, белорус. гнаіць, польск.gnоiс́. В данной глагольной форме мена звуков *[oi $>$ oj, $\overline{1}>$ i] была чисто фонетической, но альтернация *[ ø : i] выполняла словообразовательную функцию.

$$
\text { *[gei-] - “существовать” }
$$

О.и.е. корневая морфема *[gei-] послужила образованию глагольной формы продолжительного действия бессуффиксальным путём с суффиксом инфинитива *[-ť̃-]: *[geiť̌s // > žeittřs $(\check{z}<$ g) $/ />$ žitis $($ ei $>$ i) $>$ žitbs $(\breve{1}>$ b) > 
žiti (žitь)] > ст.-сл. жити, рус. жить, белорус. жыць, польск. żус́. Мена звуков в данной глагольной форме * $[\mathrm{g}: \check{z}, \mathrm{ei}: \mathrm{i}, \breve{1}:$ ь $]$ являлась чисто фоненической функцию.

Глагольная форма однократного действия развилась посредством служебных слов от глагольной формы кратного действия, например: *[pěrs geiťs $/ />$ prēs žeitǐs $(\check{e}>\bar{e}$, ei $>$ i, g $>$ ž) // > prěžitis $(\overline{\mathrm{e}}>$ ě $)>$ (prěžitbs) $(\check{1}>b)>$ prěžiti (prěžitь)] > ст.-сл. прњжити - “прожить”, рус. пережить, белорус. перажыць, польск. przeżyć. В данной глагольной форме мена звуков *[е̌ : ē > е̌, ei : i, g : $\check{z}, \breve{1}:$ ь $]$ тоже была чисто фонетической. Но префиксальная морфема * [ø : prě $<$ pěrs] выполняла формообразовательную функцию.

Глагольная форма принудительного действия развилась от той же корневой морфемы *[gei-] посредством деривационных суффиксальных морфем

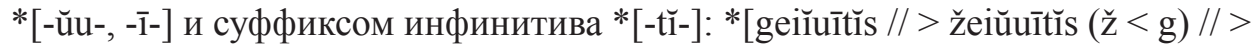

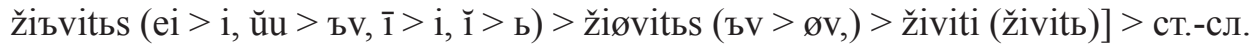
живити - “оживлять”, рус. живить - “оживлять”, польск. оżуwiać. Ср. др.инд. javati [džavati] - „живёт”, jivas [dživas] -“живой”, лит. gaivus -“добрый”.

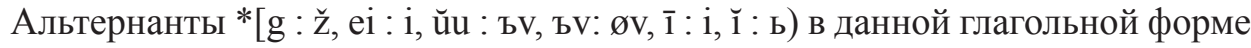
выполняли чисто фонетическую функцию. Но альтернация суффиксальных морфем *[ø : йu, $\overline{1}]$ послужила развитию иной глагольной формы. Трудно согласиться с Галиной Павловной Цыганенко, которая усматривает развитие звука *[v] в лексеме *[živiti (živitı)] - “живить” из фонемы *[u]: "Корень geiиногда распространялся звуком v < u” (Цыганенко 1970: 48). Во время развития данной глагольной формы *[v] в свободном виде ещё не было. Этот звук, как известно, развился из неслогового *[u], входившего в состав дифтонга, в последнем периоде существования праславянского языка.

На основании сопоставлений глагольных форм, сохранившихся с префиксальными лексемами в некоторых современных славянских языках, обнаруживается, что в праславянском языке выступала ещё одна глагольная форма продолжительного действия близкая по значению предыдущей глагольной форме *[živiti (živitь)]. Развилась она посредством замены суффиксального альтернанта *[ī] на *[ā] с суффиксом инфинитива *[-ť̄-]: *[geiйuātǐs // > žeiǔuātĭs $(\check{z}<\mathrm{g})>$ žibvatıs $(\mathrm{ei}>\mathrm{i}, \breve{\mathrm{l}} \mathrm{l}>\mathrm{bv}, \overline{\mathrm{a}}>\mathrm{a}, \breve{\mathrm{l}}>\mathrm{b})>$ žiøvatıs $>$ živati (živatь)] > pyc. переживать, белорус. перажываць, польск. przeżywać. Мена

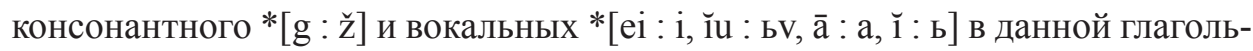
ной форме выполняла чисто фонетическую функцию, а альтернация суффиксальных морфем *[i $: \bar{a}]$ - формообразовательную финкцию.

Глагольная коренная морфема *[gei-] послужила также развитию существительных с помощью деривационных суффиксальных морфем и определённых окончаний: а) посредством деривационной суффиксальной 
морфемы *[-t-] и окончания *[ō]: *[geitŏs // > žeitŏs $(\check{\mathrm{z}}<\mathrm{g}) / />$ žitos (ei $>$ i, $\breve{o}>$ o) > žito] > ст.-сл. жито - "зерновой хлеб”, рус. жито -“всякий хлеб в зерне”, белорус. жита, польск. żyto; б) посредством суффиксальной морфемы

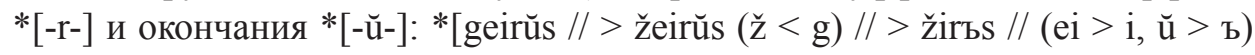
$>$ žirъ] > ст.-сл. жиръ - "корм, пажить", др.-рус. жиръ - "пастбище, богатство”, рус. жир; в) с помощью суффиксальной морфемы *[-sn-] и окончания

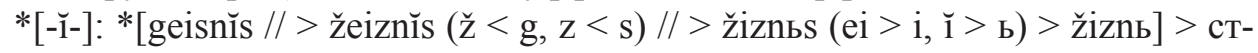
сл. жизнь - “достаток, имущество”, др.-рус. жизнь - “жизнь, оживление”, pус. жизнь, белорус. жыццё, польск. żyсіе. Ср. греч. [bios] - “жизнь” (b < g). В этих существительных консонантные и вокальные альтернанты *[g : ž, ei : i, ŭ : ъ, $\breve{1}:$ ь, sn : zn] выполняли чисто фонетическую функцию, а мена суффиксальных морфем *[ø: t, ø: r, ø:sn > zn $]$ - словообразовательную функцию.

От глагольной основы *[geiŭuі̄-] посредством замены суффиксальной морфемы *[-ī-] на *[-ŏt-] с окончанием *[-ŭ-] развилось существительное:

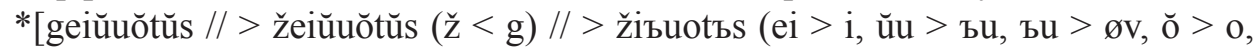
$\breve{\mathrm{u}}>$ ъ)] > žiøvotъs > životъ] > ст.-сл. животъ - “жизнь, желудок”, рус (уст.) живот, белорус. жывот, польск. żywot -,жизнь”, чеш. život - „Тж.“, в.-луж. život - "тело”. Ср. греч. [biote] - “образ жизни” (b $<$ g). В данном существительном консонантный и вокальные альтернанты * [g : ž, еі : i, ŭu : ๖u, ьu : øv, $\breve{\mathrm{o}}:$ o, ŭ : ๖] выполняли чисто фонетическую функцию, а мена суффиксальных морфем *[ī : ŏt $]$ - словообразовательную функцию.

Основа существительных явилась производящей для развития прилагательных: a) от основы *[geir-] существительного *[geirŭs > žirъ] посредством деривационной суффиксальной морфемы *[-ц̆n-] и окончания *[-ŭ-]: произошло прилагательное *[geirŭnŭs // > žeirĭnŭs $(\mathrm{g}>\mathrm{z}) / /$ žirınъs (ei $>$ i, in > ьn , ŭ > ъ) > žirьnъ] > ст.-сл. жирьн'ъ, рус. жирен, жирный; б) от основы *[geiŭuŏt-] существительного *[geiŭuŏtŭs $>$ životъ] посредством мены альтернанта суффиксальной морфемы *[-о̆t-] на *[-ø-] с окончанием *[-ŭ-]:

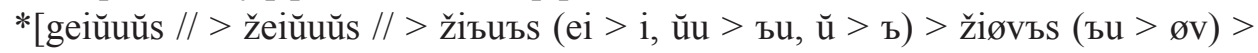
živъ] > ст,-сл. живъ ('ый), рус. живой, белорус. жывы, польск. żуwу. Ср. лит. gaivus - “добрый”, др.-инд. jivas [dživas] - “живой”; в) от основы *[geisn-] существительного *[geisnǐns $>$ žiznьnь $]$ возникло прилагательное путём наращивания суффиксальной морфемы *[-1̆n-] и окончания *[-й-] с указателем завершения слова *[-s]: *[geisnĭnŭs // > žeiznĭnŭs $(\check{z}<\mathrm{g}) / />$ žiznьnъs $($ ei $>$ i, $\mathrm{sn}>\mathrm{zn}, \mathrm{in}>\mathrm{bn}, \breve{\mathrm{u}}>\mathrm{b}$ ) > žiznьnъs > žiznьnъ] > ст.-сл. жизмемъ - “живительный, живой”, рус. жизненный, белорус. жыццёвы. Альтернация в данных прилагательных выполняла две функции: а) чисто фонетическую консонантных и вокальных *[g : ž, ei : i, ı̆n : ьn : ŭ : ъ, ŭu : ъu, ьu : øv]; б) словообразователь-

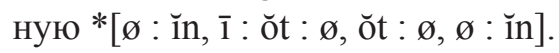




$$
\text { *[tĕk-] - "течь" }
$$

О.и.е. корневая морфема *[těk-] послужила образованию глагольной формы кратного действия бессуффиксальным путём с суффиксом инфини-

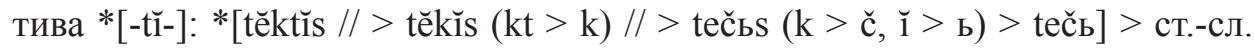
тєцтт - “течь, бежать”, рус. течь, белорус. цячы, укр. текти - “течь”, польск. ciec. Ср.: лит. tekù - “течь, бежать”, др.-инд. tákti - “спешить”. В данной

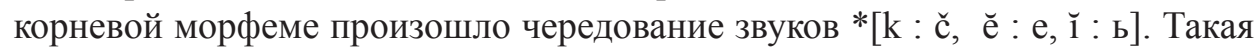
альтернация консонантных и вокальных обуславливалась чисто фонетическим явлением с целью выравнивания тона в слоге и слове и не выполняла она фонологической функции. Звук *[с $]$ являлся аллофоном фонемы *[k].

От глагольной формы $*$ [tečь $<$ těktı̌s] кратного действия образовалась глагольная форма однократного действия посредством служебных слов, впоследствии ставшими префиксальными морфемами: *[ŏus těktı̌s // > ous

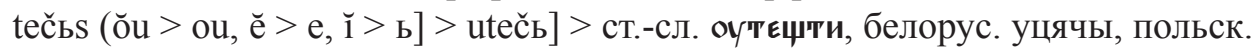

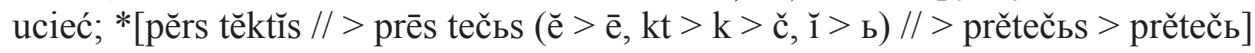
$>$ ст.-сл. прћтещти, pус. перетечь, белорус. перацячы, польск. przecieć. В данных глагольных формах альтернанты префиксальных морфем *[ø : ou, ø : prě] выполняли формообразовательную функцию.

Та же корневая морфема *[tēk-] посредством фонемного альтернанта *[e : е̌] в корневой морфеме вместе с деривационной суффиксальной морфемой *[- ā-], а также с суффиксом инфинитива *[-ť̆-] послужила развитию глагольной формы кратного действия со значением - “интенсивно течь": *[tēkātǐs // $>$ těkatıs ( $\overline{\mathrm{e}}>\mathrm{e}, \overline{\mathrm{a}}>\mathrm{a}, \breve{\mathrm{i}}>$ b) // > těkatь] > ст.-ст. тжкати - “течь интенсивно, бежать”, белорус. уцякаць, польск. uciekać, укр. тікати - „убегать”. Ср.: лит. tekéti - “интенсивно течь”. В данной глагольной форме альтернанты *[ē : ӗ, $\overline{\mathrm{a}}: \mathrm{a}, \overline{\mathrm{l}}$ : b] выполняли чисто фонетическую функцию.

Существительное развилось от глагольной корневой морфемы *[tĕk-] посредством суффиксальных морфем *[-en-, -йi-] и окончания *[-ӗ-]: *[těkenĭiĕs $/ />$ tekenijes $(\breve{\mathrm{e}}>\mathrm{e})>$ tečenijes $(\check{\mathrm{c}}<\mathrm{k})>$ tečenije] $>$ ст.-сл. течєкї̈, рус. течение, белорус. цячэнне. В данном существительном альтернанты * [k : č, ӗ : e] выполняли чисто фонетическую функцию. Но морфологические альтернанты *[ $\varnothing:$ en, няли словообразовательную функцию.

$$
\text { *[gn- > gøn- > gъn] - “гнать, преследовать” }
$$

О.и.е. корневая морфема *[gn-] послужила образованию глагольной формы кратного действия совершать движение в одном направлении посредством деривационной суффиксальной морфемы *[-ā-] и окончанием ин-

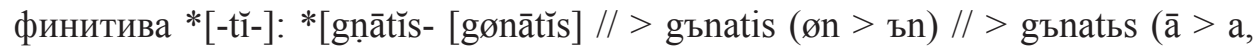


$\breve{1}>$ ь) > gъnаtь $>$ с ст.-сл. г"ъмати, рус. гнать, белорус. гнаць, польск. gnać. Ср.: лит. genù, ginti - “гнать”, др.-прусск. guntwei - “тж.”, алб. gjanj - “гоню”, др.-исл. gandz - “тонкая палка", арм. gan - “удары, побои”. Данная глагольная форма располагала альтернантами *[øn : ьn, à : a, $\overline{1}:$ ь $]$, которые выполняли чисто фонетическую функцию.

О.и.е. корневая морфема *[gṇ-] глагольной формы *[gъnatь < gṇātřs] явилась исходной при образовании глагольной формы кратного действия движения в разном направлении - с помощью мены деривационной суффик-

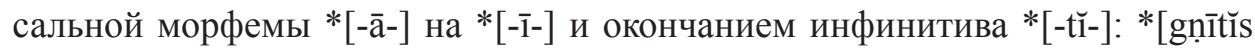
$>$ gønītĭs // > gъnitis $(\varnothing n>$ ьn, $\overline{1}>\mathrm{i}, \breve{1}>$ ь) $/ />$ gonitь $($ ьn $>$ on) $]>$ ст.-сл. гонити, pyc. гонить, польск. gonić. Ср.: др.-инд. hánti - “бьёт”. В этой глагольной форме альтернанты выполняли две функции: *[øn : ьn, ьn : on, $\overline{1}:$ i, $\breve{1}:$ ь ] - чисто фонетическую, служившую выравниванию тона в слове и слоге; *[ā : ī] - формообразовательную.

Та же о.и.е. корневая морфема * [gṇ-] глагольной формы * [gъnatь < gṇātǐs] была использована при образовании глагольной формы кратного действия, совершавшегося в разное время, в разных направлениях, посредством вставки деривационной суффиксальной фонемы *[-1і-] и окончания инфинитива

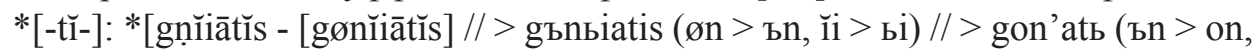
bi > 'ø, $\overline{\mathrm{a}}>$ ' $\mathrm{a}, \breve{\mathrm{i}}>$ b)] > pус. гонять, белорус. ганяць, польск. ganiać. Данная глагольная форма располагала двумя видами альтернантов: *[ øn : ъn, й : ьі

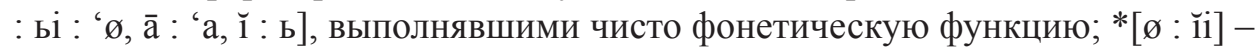
формообразовательную функцию.

Личные глагольные формы данного однокоренного гнезда настоящего времени развились от глагольной основы настоящего времени посредством суффиксальных морфем *[-о̆-, -иi-] с соответствующими окончаниями: (1-е

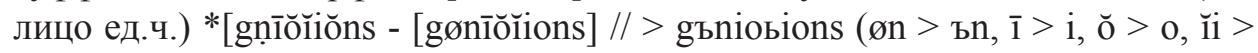
ьi, ŏn > on) //> gъniQ̨ (оьi > øj) > gъnjQ]. > ст.-сл. гоню, рус. гоню, белоpyc. (уст.) гоню, польск. gonię; (2-е лицо ед.ч. ) *[gṇīŏĭišss - [gønі̄ŏĭišss] // >

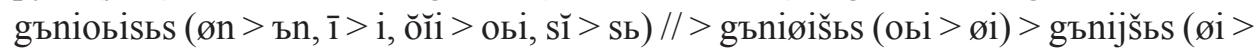
j) gъnišь (ij > i)] > ст.-сл. гониши, рус. гонишь, белорус. гоніш, польск. gonisz;

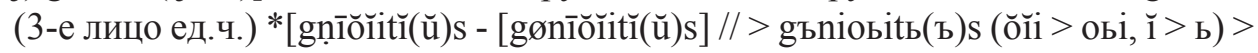
gъniøitь(ъ)s (оьi > øi) > gъniitьs (iøi > ii) $>$ gъnitь(ъ)s (ii > i) $>$ gъnitь(ъ)] $>$ ст.сл. гонить(ъ), рус. гонит, белорус. гоніт, польск. goni. Альтернация в личных

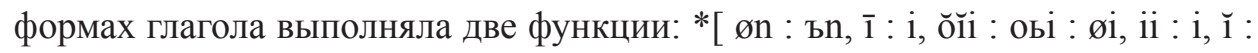
ь ] - чисто фонетическую; *[Q : šь : tь(ъ)] - формообразующую, при помощи мены личных окончаний и тематических морфем *[ о̆ї : оьі : øі : i].

Однократная форма глагола данного однокоренного гнезда достигалась при помощи служебных слов, например: *[pŏs gṇitĭs - [gønīť̌s] // > pos gъnitis

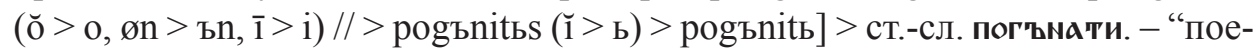
хать”, рус. погонить, польск. pogonić. В этой глагольной форме альтернанты 
*[ ŏ : o, øn : ъn, $\overline{1}:$ i, $\breve{1}: ь]$ выполняли чисто фонетическую функцию, а альтернант *[ø : ро < pŏs] - формообразовательную.

Существительные развились от той же корневой морфемы *[gn-] или глагольной основы двумя способами: а) бессуффиксальным путём с оконча-

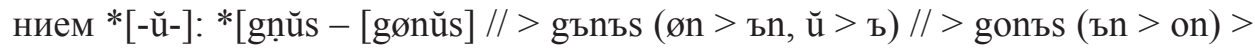
gonъ] > ст.-сл. гомъ - “погоня", рус. гон, польск. gon; б) от основы *[goni-] глагольной формы *[gonitь < gṇîtĭs] посредством разного вида деривационных суффиксальных морфем, например, *[-t-, -ŭu-]: *[gṇītŭuās - [gønītŭuās]

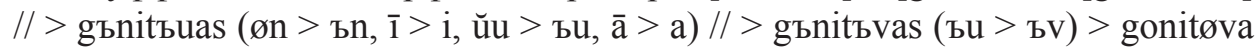
(bv > øv) ] > ст.-сл. гонитва - "преследование", польск. gonitwa. В данных

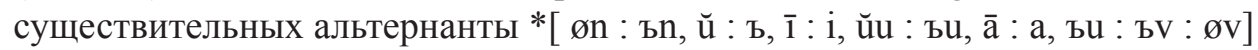
выполняли чисто фонетическую функцию, а мена $*[\varnothing: \mathrm{t}, \breve{\mathrm{u}} \mathbf{>}>\mathrm{bu}>\mathrm{bv}>\varnothing \mathrm{v}]$ в суффиксальных морфемах - словообразовательную.

Существительные также могли образовываться при помощи служебных слов от беспрефиксальных существительных *[gonъ < gṇus]: *[pŏs gṇŭs -

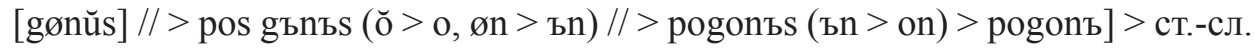
погомъ - "погоня", рус. погоня, белорус. погоня, польск. pogoń. В данном существительном альтернанты выполняли две функции: *[ о̆ : o, øn : ъn, ъn : on, $\breve{\mathrm{u}}:$ ъ $]$ - чисто фонетическую; *[ø : ро < ро̆s $]$ - словообразовательную.

*[eid-, š̌d-] - “двигаться”

Глагольные формы *[eidtı̌s, sĭdītı̌s] развились от разных корневых морфем (суплетивные). Это, как кажется, произшло по необходимости образования глагольных форм, противопоставлявшихся по действию.

Глагольная форма кратного действия - движения в одном направлении - возникла от корневой морфемы *[eid-]: *[eidť̌s > idti], а глагольная форма кратного действия - движения в разных направлениях - развилась от корневой морфемы *[sĭd- > sŏd- ] : *[š̆dītı̌s > choditь]. В корневой морфеме *[š̆d-], как кажется, произошла замена фонем *[-ॅ- : -о̆-] в связи́ с выравниванием тона в слоге и слове (акутового или циркумфлексного), но она не отразилась на содержании значения корневой морфемы. Данное предположение зиждется на анализе некоторых глагольных форм (причастия прошедшего времени), сохранившихся в старославянском и некоторых современных славянских языках. Развивались они, как известно, от основ инфинитива без мены фонем в корневой морфеме: ст.-сл. шедмъ, шьдла, шьдло, рус. шёл, шла, шло, где сочетание [-дл- > -л-], ер мягкий [-ь-] в слабой позиции выпал, в сильной - развился в ['о] (графически “ё’'); белорус. шоў, шло, шла, польск. szedl, szla, szło.

О.и.е.корневая морфема *[eid-] послужила развитию глагольной формы кратного действия - движения в одном направлении - образовалась бессуффиксальным путём с суффиксом инфинитива *[-ť̆-]: *[eidtı̌s $/ />$ istis 
(ei : i, dt : st) // > jisti ( - протетическое)] > ст.-сл. ити, рус. идти, белорус. ісці, польск. iść, серб. ити, чеш. jiti. В данной глагольной форме альтернанты * [ei : i, dt : st, ø : j] выполняли чисто фонетическую функцию.

О.и.е. корневая морфема *[š̆d-] явилась источником образования глагольной формы кратного действия посредством замены в корневой морфеме

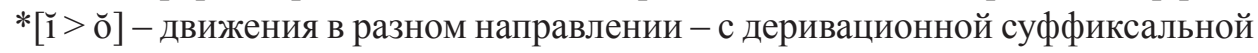

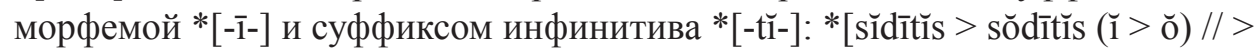

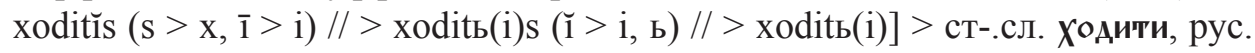
ходить, белорус. хадзіць, польск. chodzić. В этой глагольной форме альтернация выполняла чисто фонетичускую функцию: *[ $[\breve{1}: \breve{o}, \mathrm{~s}: \mathrm{x}, \overline{1}: \mathrm{i}, \breve{1}:$ ь $]$.

От корневой морфемы *[sŏd- < š̆d-] развилась глагольная форма кратного действия - многократно ходить - посредством альтернации вокальных фонем в корневой морфеме *[-о̆- : -о̄-] (долгота вокальных, как известно, указывала на продолжительность действия или состояния) и деривацион-

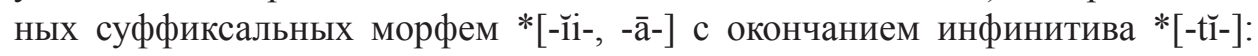
*[sōdřiâtǔs // > xōdǔiātřs $(\mathrm{s}>\mathrm{x}) / />$ xadbiatıs $(\overline{\mathrm{o}}>\mathrm{a}, \breve{1 i}>\mathrm{bi}, \overline{\mathrm{a}}>\mathrm{a}, \breve{\mathrm{i}}>\mathrm{b})>$ xadøiatbs ( ьi > øi) > xadžatь $($ døi > dž $)]>$ ст.-сл. ХажАати, рус. (уст.) хаживать $<$ хажати, польск. chadzać. В данной глагольной форме альтернанты * [ o : a, й : ьi, ā : a, ьi : øi, d : dž, $\breve{1}:$ ь] выполняли чисто фонетическую функцию, а альтернанты *[ᄃ : $\overline{\mathrm{o}}, \overline{1}: \breve{1} \mathrm{i}, \overline{\mathrm{a}}]$ - формообразовательную.

От той же глагольной корневой морфемы *[sŏd-] образовались существительные двумя способами: а) бессуффиксальным путём с окончанием

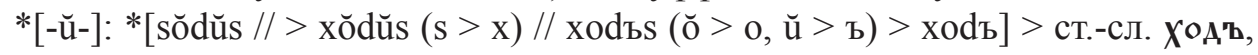
рус. ход, белорус. ход, польск. chód; б) посредством деривационных морфем

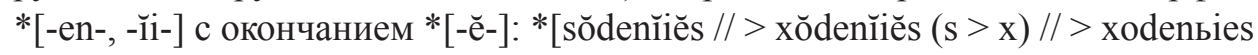
$(\breve{o}>0, \breve{1 i}>$ bi, $\breve{e}>$ e $)>$ xodenøies $($ bi $>\varnothing i)>$ xodženje $($ den $>$ džen, $\varnothing \mathrm{i}>\mathrm{j})]>$ ст.сл. Хожденіє, рус. хождение, белорус. хадженне, польск. chodzenie. В данных

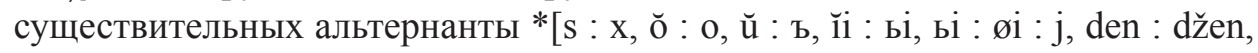

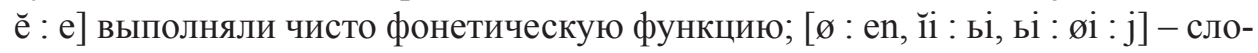
вообразовательную функцию.

Причастия - одна из глагольных форм, как кажется, уже выступали в о.и.е. языке, так как причастия известны и другим языковым группам индоевропейской семьи. Например, действительные причастия настоящего

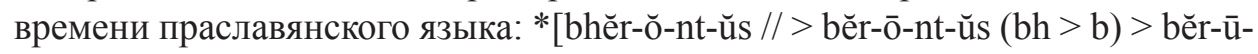
ntŭs $(\overline{\mathrm{o}}>\overline{\mathrm{u}}) / />$ beryntъ $(\overline{\mathrm{u}}>\mathrm{y})>$ berynt $>$ bery (nt отпало)] $>$ ст.-сл. керъ (рус. берущий). Сp. др.-инд. bharantam, греч.[férŏnta], лат. ferentem ( $<$ bh). Мы остановимся только на некоторых дискуссионных образованиях причастий, где выступала мена консонантных в корневой морфеме.

Действительные причастия прошедшего времени, как известно, образовывались посредством суффиксальной морфемы *[-й-] и указателя конца слова *[-s] от основы инфинитива, оканчивавшейся на суффиксальные во- 


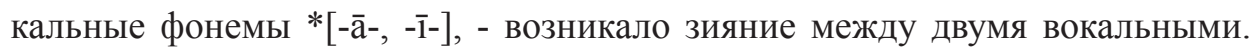
Такого явления со словесным ударением язык не терпит, так как оно препятствовало плавному произношению слова. В начальном периоде праславянского языка оно было характерным при отсутствии словесного ударения вообще, так как произношение слов было посложное. С развитием словесного ударения в следующих периодах существования языка, в частности музыкального, требовавшего построения слога от консонантного к вокальному. Возникала необходимость использования вставки консонантного между вокальными, т.е. протезы. Протезами в праславянском языке были только неслоговые *[u, i]. В данном причастии после вокального заднего ряда могла выступать протеза *[u] неслоговое, а после вокального переднего ряда - *[i] неслоговое. Так возникли вторычные дифтонги: *[snā-ŭ-s // > znā-ŭ-s $(\mathrm{s}>\mathrm{z}) / />$ znā-u-ŭ-s $>$ zna-v-ŭ-s $(\overline{\mathrm{a}}>\mathrm{a}, \mathrm{u}>\mathrm{v})>$ zna-v-b-s $(\breve{\mathrm{u}}>\mathrm{b})>$ znavъ $]$

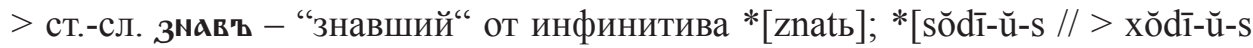

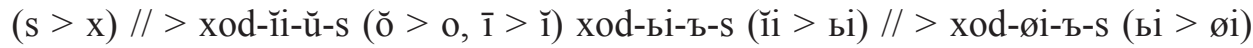
$>$ xоd-øj-ъs $>$ xodž'ьs $($ døj $>$ dž', ь $>$ ь) $>$ хоdž'ь $>>$ ст.-сл. Хождь - “ходивший”, где *[1] перед *[J] редуцировалось из-за близости по качеству этих двух звуков, а ер твёрдый *[ъ < й] после *[j] переходил в ер мягкий *[ь]. Согласно мнению Хабургаева в причастиях, образовавшихся от глагольной основы на суффиксальный*[-i-], не было протезирования, а *[-i-] в основе инфинитива изменялся в *[-j-] ,перед гласным причастного суффикса ещё в праславянском языке конечный *і в основе инфинитива изменялся в $*_{\mathrm{i}}>*_{\mathrm{j}}$, , (Хабургаев 1974: 297).

В славянских языках, как известно, существуют две глагольные основы: основа инфинитива и основа настоящего времени. Основа настоящего времени должна отличаться от основы инфинитива по составу деривационных морфем. В старославянском языке основа настоящего времени определяется по содержанию так называемого тематического гласного в отличии от основы инфинитива. Такими тематическими вокальными (суффиксом) в старославянском языке считаются [е, и, о]. Однако не во всех личных формах глагола эти морфемы выступают. Считается, что они (морфемы) унаследованы из праславянского языка, но не сохранились во всех личных глагольных формах. Об этом засигнализировал Хабургаев, что в 1-ом лице sg. и в 3-ем лице pl. не сохранилось тематического гласного (Хабургаев 1974: 258). По нашему мнению, основа настоящего времени развилась от основы инфинитива посредством деривационных морфем *[-о̆-, -йі-] во всех лицах, а указанные тематические вокальные - учитывая развитие музыкального словесного ударения и его следствия - являются лишь остатком исконных морфем.

Несохранившиеся деривационные морфемы из праславянского языка в старославянском языке в 1-ом лице ед. ч. и в 3-ем лице мн. ч. , по нашему мнению, можно восстановить на основании оставшихся “следов” в этих 
личных глагольных формах, основа которых в инфинитиве завершалась заднеязычным * $[\mathrm{g}, \mathrm{k}, \mathrm{x}]$ и консонантным * $[\mathrm{s}, \mathrm{z}, \mathrm{t}, \mathrm{d}, \mathrm{b}, \mathrm{p}, \mathrm{v}, \mathrm{m}]$, используя закономерности их изменений в фонетической позиции перед *[e, ь], например: 1-е лицо sg. *[nŏsīŏíiŏns // > nosiobions ( $\breve{o}>$ o, $\overline{1}>\mathrm{i}, \breve{\text { ŏii }}>$ obi, ŏn $>$ on) // > nosbions

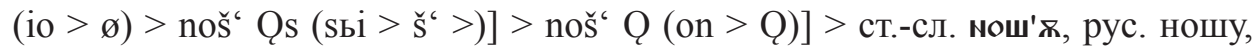
белорус. нашу, польск. noszę. В последнем периоде развития праславянского языка выпало сочетание двух вокальных *[io], создававшее “зияние” (перерыв в артикуляции между двумя вокальными), препятствовавшее плавности

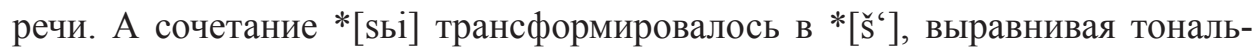
ность в слове. Альтернанты этой личной глагольной формы * [ŏ : o, $\overline{1}:$ i, ŏ1i : оьi, ŏn : on, io : ø, on : Q, sьi : š‘] выполняли чисто фонетическую функцию, не отражавшуюся на значении лексемы.

Возникает вопрос: Почему не произошла трансформация *[s] в личной глагольной форме, образовавшейся от глагольной основы однокоренного гнезда *[nе̌s-] глагола *[něstĭs]: 1-oе лицо sg. *[něsǒĭiŏns // nesobions (ě > e, ŏi > оьi, ŏn > on $)>$ nesons $($ оьі > $>$ ) > nesQs (on > Q] > ст.-сл. месж, рус. несу, белорус. нясу, польск. niosę? Альтернанты *[ е̌ : e, ŏí : оьі, ŏn : on, оьі : ø] выполняли чисто фонетическую функцию. Сочетание *[оьі > $]$, препятствовавшее плавности произношения, выпало. Консонантный *[s], оказавшийся перед вокальным *[o], как известно, в такой фонетической позиции не подвергался изменению.

Также возникает вопрос: Почему не трансформировался тот же консонантный *[s] в 3-лице pl. однокоренных лексем *[nŏs-, něs-]:

a) *[nŏsīŏinintŭs // > nosiobintъs ( $\breve{o}>0, \overline{1}>$ i, ŏhi > obi, ŭ $>$ b) $>$ nosbintъs (oi

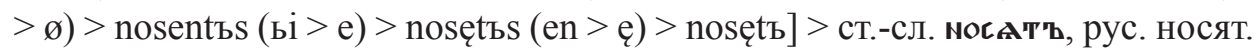
польск. noszą. В этой глагольной форме альтернанты *[ о : o, i : i, ŏ1i : оьі, $\breve{\mathrm{u}}:$ ь , oi : ø, ьi : e, en : е] являлись чисто фонетическими, служившие созданию плавности произношения данной глагольной формы. Сочетание двух гласных *[оі] выпало, так как между ними происходил перерив артикуляции (зияние).

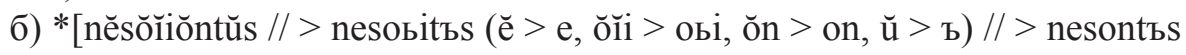

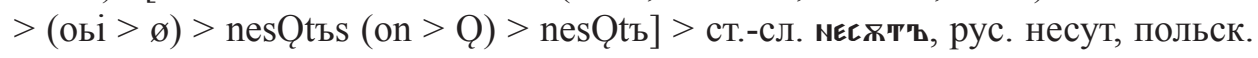
niosą. В данной глагольной форме альтернанты *[ е : e, ŏı̆i : oьi, ŏn : on, ŭ : ъ, оьі : ø, on : Q] выполняли чисто фонетическую функцию. Сочетание *[оьі] по поводу “зияния" между двумя вокальными выпало. В этих глагольных формах однокоренного гнезда консонантный *[s] оказался в положении перед фонемой *[o], неспособствовавшей трансформации.

Примеры личных глагольных форм, основа в инфинитиве которых заканчивалась на вокальный: 
От основы *[zna-] глагола [znatь < gnōtǔs]: (1-e лицо sg.) *[gnōǒĭiŏns // > znaoŭions ( $\mathrm{g}>\mathrm{z}, \overline{\mathrm{o}}>\mathrm{a}, \mathrm{ŏhi}>$ оьi $>$ ŏn $>$ on) // > znaobions > znaoøions (ьi > øi) $>$ znaøiQ̨s (on > Q)] > znaøiQ] > ст.-сл. змањя, рус. знаю, польск. znат. В этой глагольной форме консонантные и вокальные альтернанты * $[\mathrm{g}: \mathrm{z}, \overline{\mathrm{o}}: \mathrm{a}, \breve{\mathrm{e}}$ : e, ŏíi : оьi, ŏn : on, ŭ : ъ, оьі : ø, on > Q] выполняли чисто фонетическую функцию, сочетание *[оь < о̆1] выпало как избыточный элемент в создании плавности произношения этой глагольной фомы, но альтернанты *[ø : ǒíi] выполняли формообразовательную функцию.

От глагольной основы *[xodi-] глагола *[xoditь < sŏdītǐs] (1-e лицо sg. ) *[sŏdīŏíiŏns // > xodiobions ( $\mathrm{s}>\mathrm{x}, \breve{\mathrm{o}}>\mathrm{o}, \overline{1}>\mathrm{i}$, ŏíi $>$ оьi, ŏn $>$ on) // > xodøions (io $>\varnothing),>$ xodžons $($ døi $>$ dž $)>$ xodžQ̨s $($ on $>$ Q) $>$ xodžQ] $>$ ст.-сл. ХожА'к, pyc. хожу, белорус. хаджу, польск. chodzę. В этой глагольной форме консонантные и вокальные альтернанты *[s : x, о̆ : o, $\overline{1}:$ i, ŏí : оьi, io : ø, ŏn : on, døi : dž‘, on : Q] выполняли чисто фонетическую функцию, сочетание * [io < 1̄ŏ] выпало как препятствующий элемент в создании соответствующего в слове тона, а альтернанты *[ø : о̆іi - формообразовательную функцию;

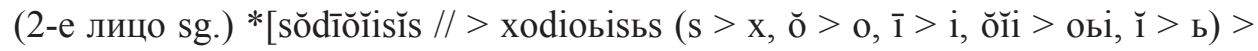
xodbisbs $($ io $>\varnothing)>$ xodiš'bs $\left(\right.$ ьi $>$ i, sь $\left.>\check{s}^{\varsigma}\right)>$ xodiš' ходишь, белорус. ходіш, польск. chodzi. В этой глагольной форме консонантные и вокальные альтернанты *[s : x, ŏ : o, $\overline{1}:$ i, ŏí : obi, io : ø, ŏn : on, on $: \mathrm{Q}$, ьі $\left.: \mathrm{i}, \mathrm{s}: \breve{s}^{‘}\right]$ служили выравниванию тона в слове, т.е. выполняли чисто фонетическую функцию, вокальное сочетание * [io < 1̄ŏ] выпало как избыточный элемент в создании тона в слове, а альтернанты *[ø : о̆іi] - формообразовательную функцию; (3-е лицо pl.) *[ sŏdīŏìtŭs // xodiobitъs (s > x, ŏ >

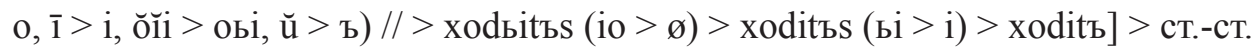
Ходит'ъ, рус. ходит, белорус. ходзіць, польск. chodzi. Консонантный и вокальные альтернанты данной глагольной формы *[s : x, ŏ : o, $\overline{1}:$ i, ŏii : оьі, io : ø, ŏn : on, on : Q, ŭ > ъ] выполняли чисто фонетическую функцию, сочетание *[io < $\overline{10 ̆}]$ выпало, препятствовавшее плавности произношения, но альтернанты *[ø : о̆іi $]$ - формообразовательную функцию.

Личные глагольные формы, которых основа в инфититиве оканчивалась на *-non-]:

От глагольной основы *[dvignon-] глагольной формы *[dvignontь < dŭuīgnontǐs]: (1-е лицо sg.) *[dŭuīgnonǒĭiŏns // > dъvignonobions (ŭu > bv,

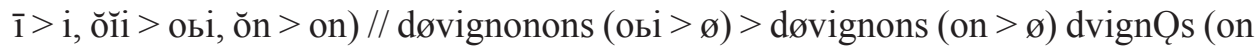
$>$ Q) $>$ dvignQ] $>$ ст.-сл. двигнд, рус. двигну. В данной глагольной форме альтернанты *[ŭu : ๖v, î : i, ŏii : obi, ŏn : on, obi : ø, on : ø, on > Q] выполняли чисто фонетическую функцию, сочетания *[on, оьi < о̆іi] выпали как избыточный элемент, препятствовавший созданию тона в слове, а альтернанты *[ø : ŏіi несли формообразовательную функцию; (2-е лицо sg.) *[dŭuīgnonǒĭišs //

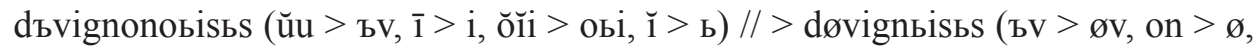


o > ø) > dvignešьs (ьi > e, sь > š ь) > dvigneš’ нешь. В этой глагольной форме консонантные и вокальные альтернанты

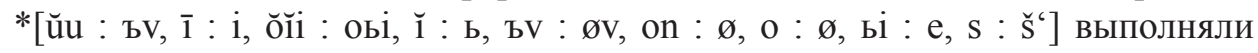
чисто фонетическую функцию, сочетание *[on] и вокальный *[o] выпали как избыточный элемент, препятствовавший в создании тона, а альтернанты *[ø : ŏì] - формообразующую функцию; (3-е лицо sg.) *[dŭuīgnonǒĭitŭs //

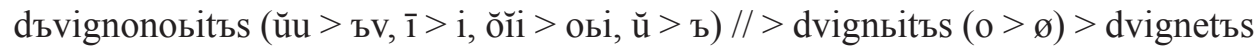
$($ ьі > e) $>$ dvignetъ $]>$ ст.-сл. Авигнет' имели формообразовательное значение; (3-е лицо pl.) *[dŭuīgnonǒĭintŭs //.>

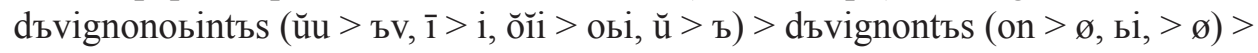
dъvignQtъs $($ on $>$ Q) $>$ døvignQt $(\mathrm{bv}>\varnothing \mathrm{v})]>$ ст.-сл. .двигнжт $\mathbf{k}$, рус. двигнут. Данная глагольная форма располагала альтернантами *[ŭu : ъv > øv, ī : i, ŏı̆i : оьі, $\breve{\mathrm{u}}:$ ь, on : ø, ьі : ø, on : Q], выполнявшими чисто фонетическую функцию, сочетания *[on, ьi] выпали как избыточный элемент, но *[ø : о̆іi] - формообразующую функцию.

Итак, в праславянском языке основа личных глагольных форм образовывалась от основы инфинитива посредством деривационных суффиксальных морфем *[-о̆-, -й-] - кроме так называемых нетематических глаголов от которой (после всевозможных трансформаций) остались только “следы” в 1-ом лице sg. и в 3-ем лице pl., а в остальных лицах незначительная её часть *[e, i]. Отсутствие трансформаций, перечисленных выше консонантных фонем, обуславливается их фонетической позицией, т.е. сочетаемостью не с фонемами переднего ряда *[e, ь $]$.

Таким образом, альтернация в праславянском языке выполняла две функции: чисто фонетическую и слово-формообразовательную.

Вокальные и консонантные альтернанты, выступавшие в одной и той же лексеме, служили для создания тона в слоге и слове. А являлись они следствием развития словесного ударения, в частности музыкального, так как о.и.е. язык, как кажется, был монотонным и коммуникативность языка могла обеспечить сама фонологическая система. В праславянском языке сама фонологическая система уже не могла обеспечить потребности языковой коммуникативности. Тогда языку необходимо было прибегать к какому-то приёму, восполнявшему фонологическую систему. Им оказалось словесное ударение, которое вместе с фонемами выполняло фонологическую функцию. Словесное ударение, в частности музыкальное, зиждется на создании плавности речи. Количественная характеристика вокальных и качественная характеристика некоторых консонантных препятствовала такому созданию речи, которое вызвало их трансформацию. Отсюда вокальные и консонантные каждого следующего периода развития языка являлись аллофонами предыдущего периода, например: *[nŏrŭkās > norъkas $(\breve{o}>0, \breve{u}>$ b, $\bar{a}>a)>$ 
norъka] - рус. норка. Здесь альтернанты *[ $\breve{o}:$ o, ŭ : ъ, à : a] выполняли чисто фонетическую функцию.

Альтернанты вокальных или дифтонгов в корневых или суффиксальных морфемах, кроме фонетической функции, выполняли ещё слово- формообразовательную функцию: *[1ēkstētǐs // > lētētǐs (ks - выпало) // > lětěti(ь)s $(\overline{\mathrm{e}}>$ ě, $>\overline{\mathrm{e}}>$ ě) $>$ lětěti(ь)] - рус. лететь и *[lēkstātǐs $/ />$ lētātǐs $(\mathrm{ks}$ - выпало) $/ />$ lětati(ь)s $>(\overline{\mathrm{e}}>$ ě, $\overline{\mathrm{a}}>\mathrm{a})>$ lětati(ь)]- рус. летать. В этой паре глагольных форм вокальные альтернанты выполняли чисто фонетическую функцию

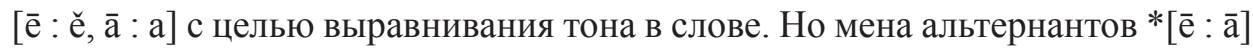
в суффиксальных морфемах служила образованию глагольных форм. А развитие существительного от глагольной корневой морфемы произошло пос-

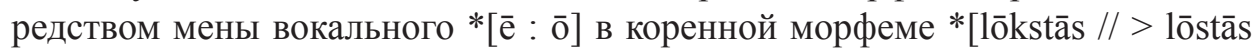
(k- выпало) // > lastas ( $\overline{\mathrm{o}}>\mathrm{a}, \overline{\mathrm{a}}>\mathrm{a})>$ lasta] - рус. ласточка. В данном существительном альтернанты *[ō : a, $\bar{a}:$ a] служили выравниванию тона в слове,

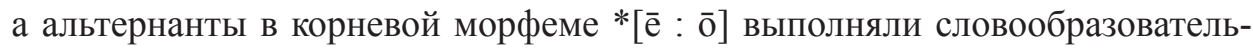
ную функцию.

Альтернанты консонантных в корневых и суффиксальных морфемах, трансформировавшиеся в определённый звук, являлись только аллофонами соответствующих консонантных и не выполняли словообразовательной функции: *[gei-s-nĭs //> gei-z-nĭs $(\mathrm{s}>\mathrm{z}) / />$ ži-z-nьs $\left(\mathrm{g}>\check{z ̆}^{6}\right.$, ei $>\mathrm{i}, \breve{1}>$ ь) $>$ ž‘iznь - рус. жизнь. Здесь альтернанты *[ g : ž, s : z]; *[kaiā-s-nĭs //> ka-znьs $(\mathrm{s}>\mathrm{z}) *[\mathrm{ai}]$ - выпало как препятствующий элемент в создании тона) // > kaznь $]>$ pyc. казнь. В лексеме казнь альтернанты* $[\mathrm{s}: \mathrm{z}] ; *$; $\overline{\mathrm{u}}-\mathrm{s}-\mathrm{is} / /$ my-s-ьs

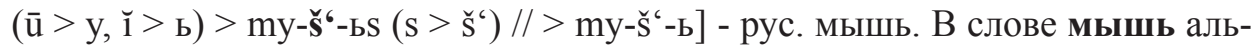
тернанты $*\left[\mathrm{~s}: \breve{s}^{\natural}\right) ; *[$ mŭ-s-kŭs //> mŭ-s-ŭs (к - выпало) $>$ mъ-s-ъs $(\breve{\mathrm{u}}>$ ъ) $/ /$ $>$ mъ-х-ъs $(\mathrm{s}>\mathrm{x})>$ mъхъ $]$ - рус. мох. В лексеме мох альтернанты *[s : x]. Во всех приведённых примерах консонантные альтернанты выполняли чисто фонетическую функцию, являвшуюся следствием развития музыкального словесного ударения. Но альтернанты суффиксальных морфем, которые явились результатом мены при образовании других частей речи, выполняли словообразовательную функцию.

Образование существительных от глагольных морфем проходило двумя способами: а) бессуффиксальным путём, например, от глагольной корневой морфемы *[bei-] глагольной формы *[biti(ь) < beitǐs] : *[boiŭs $>$ boiъs $>$ bојъ] > рус. бой; от корневой морфемы *[gnei-] глагольной формы *[gniti(ь) $<$ gneitǐs] : *[gnoiŭs $>$ gnoiъs $>$ gnojъs $>$ gnojъ] $>$ рус. гной. В данных словоформах в корневых морфемах произошла мена дифтонгов *[еі : оі], выполнявших словообразовательную функцию, тем самым образуя другую часть речи; б) посредством суффиксальных морфем. В таких существительных, как правило, не происходило чередование в корневых морфемах. Словооб- 
разовательную функцию выполняли суффиксальные морфемы, например: *[gei-] *[žito < geiť̌s]: *[geitǒs $>$ žitos $>$ žito] > pyc. (уст) жито; от глагольной корневой морфемы *[gnei-] глагольной формы *[gniti(ь) < gneiť̌s]: *[gneilı̌s] $>$ gnilьs $>$ gnilь $]>$ pyc. гниль. Отсутствие мены вокальных или дифтонгов в корневых морфемах, развившихся от глагольной корневой морфемы, можно предположить, что это результат музыкального словесного ударения (акута или циркумфлекса).

\section{STRESZCZENIE}

Artykuł podejmuje próbę ustalenia funkcji alternacji wokalnych i konsonantnych fonemów zarówno w morfemach rdzennych, jak też w morfemach derywacyjnych. Analiza ta została sporządzona według okresów rozwoju języka prasłowiańskiego. Wyodrębnia się je na podstawie zachodzących istotnych zmian fonologicznych głosek. W artykule szczególnej analizie poddane są formy osobowe czasowników, których temat zarówno w języku starosłowiańskim, jak i we współczesnych językach słowiańskich kończy się na tak zwaną samogłoskę tematyczną. Badaniem zostały objęte przeważnie wyrazy utworzone od rdzeni języka praindoeuropejskiego. O ich pochodzeniu świadczy fakt, że rdzenie te występują w wielu językach indoeuropejskich.

Słowa klucze: alternacja, funkcja, fonologia, morfologia, samogłoski, spółgłoski.

\section{SUMMARY}

The paper attempts to determine the function of vocal and consonant alternations of phonemens in both root and derivational morfems. This analysis has been carried outby development periods of the Proto-Slavic language. Such periods are identified based on significant phonological changes of speech sounds. The paper includes a specific analysis of personal verb forms, whose stem ends in the so-called stem vowel in Old Church Slavonic as well as in modern Slavic languages. The research primarily encompassed the words derived from the roots of the Proto-Indo-European language. Their origin is confirmed by the fact that these roots are found in many Indo-European languages.

Keywords: alternation, funktion, phonology, morphology, vowels, consonants.

\section{BIBLIOGRAFIA}

Bednarczuk L. et al, 1986, Języki indoeuropejskie, t. 1, Warszawa.

Czerniakiewicz J., 2003, Некоторые особенности просодии (ударения) и отражения её на структуре слога „Przegląd Rusycystyczny” nr 2.

Klemensiewicz Z. et al., 1981, Gramatyka historyczna języka polskiego, Warszawa.

Kuryłowicz J., 1956, L'apophone en indo-europeen. Apofonia w językach indoeuropejskich, Wrocław.

Kuryłowicz J., 1957, O jedności językowej bałto-słowiańskiej, „Biuletyn Polskiego Towarzystwa Językoznawczego", t. XVI.

Milewski T., 1969, Z zagadnień językoznawstwa ogólnego i historycznego, Warszawa.

Polański K. (red.), 2003, Encyktopedia językoznawstwa ogólnego, Wrocław.

Vaillant A., 1966, Grammaire compareé des langues slaves, III: Le verbe, Paryż. 
Беседина-Невзорова В. П., 1962, Старославянский язык, Харьков.

Бошкович Р., 1984, Основы сравнительной грамматики славянских языков. Фонетика и словообразование, Москва.

Кривчик В. Ф., Можейко Н. С., 1970, Старославянский язык, Минск.

Хабургаев, Г. А., 1974, Старославянский язык, Москва.

Цыганенко Г. П, 1970, Этимологический словарь русского языка, Киев.

Шведовой Н. Ю. (ред.), 1970, Грамматика современного русского языка, Москва. 